\title{
Hot Air Drying and Quality of Red and White Varieties of Onion (Allium cepa)
}

\author{
Ayoola Olalusi \\ Department of Agricultural and Environmental Engineering, Federal University of Technology, Akure, Nigeria \\ Email: ayoolalusi@yahoo.com, apolalusi@futa.edu.ng
}

Received 20 August 2014

\begin{abstract}
This study was undertaken to investigate the drying characteristics of red and white varieties of onion (Allium cepa) in a convective dryer. The drying characteristics of onion slices were examined at air temperatures of $50^{\circ} \mathrm{C}, 60^{\circ} \mathrm{C}$ and $70^{\circ} \mathrm{C}$ and sample thicknesses of $2 \mathrm{~mm}$. During the drying experiments, air velocity was held stable at $0.9 \mathrm{~m} / \mathrm{s}$. The effects of air temperature on the drying characteristics and quality parameters such as vitamins $\mathrm{C}$ and $\mathrm{D}$, macro minerals $(\mathrm{Mg}, \mathrm{Na}, \mathrm{P}$, $\mathrm{Ca}$ and $\mathrm{K}$ ), non-enzymatic browning and thiolsulphinate of the dried onion slices were determined. For each of the plots of the drying curves from the mechanical drying tests, there was an absence of or just a very brief appearance of a constant rate period because onions are hygroscopic and hygroscopic foods tending to quickly enter the falling rate period; drying time decreased considerably with increased temperature. The time required to reduce the moisture content to any given value was dependent on the drying conditions, being the longest at an air temperature of $50^{\circ} \mathrm{C}, 0.9 \mathrm{~m} / \mathrm{s}$ and the shortest at an air temperature of $70^{\circ} \mathrm{C}$ and air velocity of $0.9 \mathrm{~m} / \mathrm{s}$. The loss of vitamin $\mathrm{C}$, which is a thermo-sensitive compound, was the least at an air temperature of $50^{\circ} \mathrm{C}$.
\end{abstract}

\section{Keywords}

Air Temperature, Onion, Drying Characteristics, Quality, Moisture Content

\section{Introduction}

Onion (Allium серa) has been widely used even in ancient times as seasonings, for medical uses and as foods [1]. The importance of onions lies in the flavour that it imparts to several other dishes. Onion is characterized by its distinctive flavour and pungency which are due to sulphur containing compounds available in the scales of bulbs. Onion is a basic flavouring in the kitchen. It is used as a vegetable, or as a spice to bring out the flavour of other dishes without overpowering them. Onions are the indispensable vegetable, the strong (yet sweet) cornerstone of modern cooking, not just in our culture but around the world. For centuries, onions have been thought to have certain medicinal and disease prevention powers; modern science has begun to show that there may be some fact in the ancient lore. At the same time, onions are low in calories and are a source of dietary fiber. Bulb onions also provide vitamin $\mathrm{C}$, with one medium onion providing 15 to 20 percent of the daily requirement. In the United States, products that contain onion extract are used in the treatment of topical scars [21]; some studies 
have found their action to be ineffective, while others found that they may act as an anti-inflammatory or bacteriostatic [3]. 3-Mercapto-2-methylpentan-1-ol in onion was found to have an antioxidant potent that inhibits peroxynitrite-induced diseases.

In Nigeria, onion (Allium cepa) is majorly used as a flavouring agent. There is a general increase in demand for processed onions because of the high perishability of fresh onion. To satisfy this demand several types of natural onion products are currently available to food processors. These include dehydrated onion in powder or pieces: onion oil obtained by the distillation of fresh onions and offered as is diluted in vegetable oil or in form of an emulsion; onion juice concentrated to a viscous syrup or thick paste and also offered in dry form as dispersion on salt or dextrose [4]. Most of these processed onions are imported into the country.

Onions stored for long periods are subject to storage rot, sprouting, rooting, and loss of water making dehydration necessary as a method of preservation [5]. Prices of onion tend to oxalate during the dry season before harvest begins, due largely to the inability of the farmers to store the highly perishable crop. Preparing onions are often accompanied by watery eyes, caused by the breakdown of onion cells when cut; these cells release sulphurous substances that are in contact with the surrounding air, and create a new molecule (allyl sulphate) that irritates the eyes; the stronger the onion, the more it stings the eyes. Also the appearance of pieces of onions is not generally acceptable by people despite the love for onion flavour in most of their foods.

The rate of browning reaction is influenced strongly by the temperature and the moisture content of the food during drying; drying temperatures above $65^{\circ} \mathrm{C}$ have a significant influence on the colour of dried onion [6] [7]. This has led to the demand for increase in the efficiency of onion dehydration to obtain a high-quality finished product. The objective of this work is to determine the effects of air temperature on the drying characteristics and quality of red and white onion varieties.

\section{Materials and Method}

\subsection{Materials}

\subsubsection{Onions}

Two fresh well graded onion varieties, namely Red and White were purchased from a local market (Iloro) in Akure, Ondo State, Nigeria. The onions were peeled manually by removing the skin and the first layer. After peeling, it was washed with tap water and left on an aluminum trays for 1 hour to allow the residual wash water on the surface of the onions to evaporate, the onions were sliced using a vegetable slicer in the direction perpendicular to the vertical axis. The onion slices were $2 \mathrm{~mm}$ thick.

\subsubsection{Experimental Dryer}

The drying experiments were conducted in a laboratory using the mechanical convective dryer [8] which consists of the following: centrifugal blower, a heating chamber (with 2-no $1.5 \mathrm{~kW}$ heater), a plenum chamber and a drying chamber. The air velocity could be kept constant during drying experiments at any desired level ranging from 0.3 up to $1.8 \mathrm{~m} / \mathrm{s}$.

The air passes into the central section of the duct where four trays of the material to be dried are suspended in the air stream. The entire dryer was insulated to avoid heat losses and substantial temperature differences across the test sections. The temperature of the air stream was measured by means of k-type thermocouples and controlled by a power regulator. Drying air velocity was measured by means of a hot-wire anemometer. The onion slices (2 mm thick) were spread in a net placed on the baskets which were made from stainless steel wire net.

\subsection{Experimental Procedures}

\subsubsection{Drying Experiment}

The dryer was run idle for about 1 hour to achieve a steady state in respect of pre-set experimental drying conditions before each drying run. About $100 \mathrm{~g}$ of onion slices after weighing were uniformly spread on the net and placed in the basket inside the drying chamber. The weight of the onion samples (white and red onions) was measured at intervals of 30 minutes. Drying was stopped when there was no noticeable change in the weight of the samples. The mechanical drying experiments were conducted at $0.9 \mathrm{~m} / \mathrm{s}$ air velocity and $50^{\circ} \mathrm{C}, 60^{\circ} \mathrm{C}$ and $70^{\circ} \mathrm{C}$ air temperatures. 


\subsubsection{Analytical Methods}

The moisture content of fresh onion and the moisture content of the dried products were determined using the oven method [9]. The extent of brown pigment formation in the onion samples was determined by the measurement of the optical index. Phosphorus was determined routinely by the Vanado-Molybdate colorimetric or Spectrophotometric method. Thiolsulphinate, vitamins D, ascorbic acid (vitamin C), calcium, potassium and sodium content were determined using the official method of A.O.A.C. [10].

Sensory evaluation was performed on the dried-milled onion samples using 20 panelists [11]. The product was evaluated on quality characteristics of texture, appearance, aroma, taste, feel and general acceptability on a 9-point Hedonic scale rating with 9 as like extremely and 1 as dislike extremely. The scores were then subjected to analysis of variance (ANOVA). Panelists were from the university community and cut across age and sex.

\section{Results and Discussion}

\subsection{Effect of Drying Air Temperature on Drying Characteristics of Onions}

The graphs of moisture content versus drying time and drying rate versus drying time at air velocity of $0.9 \mathrm{~m} / \mathrm{s}$ and air temperature of $50^{\circ} \mathrm{C}, 60^{\circ} \mathrm{C}, 70^{\circ} \mathrm{C}$ are shown in Figure 1 and Figure 2 for the red and white onion varieties respectively. The drying curves are typical to ones for food stuffs. The moisture content of onion slices decreased exponentially with elapsed drying time. As the air temperature increased, other drying conditions being same, the drying curves became steeper indicating higher moisture removal rates thus resulted into substantial decrease in drying time (t). At air velocity of $0.9 \mathrm{~m} / \mathrm{s}$ drying time for the onion slices at air temperature of $50^{\circ} \mathrm{C}$, $60^{\circ} \mathrm{C}$ and $70^{\circ} \mathrm{C}$ were about $13 \mathrm{~h}, 12.5 \mathrm{~h}$ and $11 \mathrm{~h}$, respectively. The moisture content reduced rapidly at the beginning and then decreased slowly with increase in drying time. Both the external factors and the internal moisture transport mechanism controlling the drying processes in the two main drying time regimes are important in determining the overall drying rate of the product [12]. The drying rates were higher in the beginning of the drying process and gradually reduced as the drying process progressed. This was because of more heat energy is absorbed by the water at the product surface initially, resulting into faster drying, and with the product surface drying out subsequently, heat penetration though the dried layer decreased thus retarding the drying rates. The drying rates increased with increase in air temperature, other conditions remaining the same and thus reducing the drying time. The dehydration rate of onion slices was found to be greatly dependent on the air temperature.

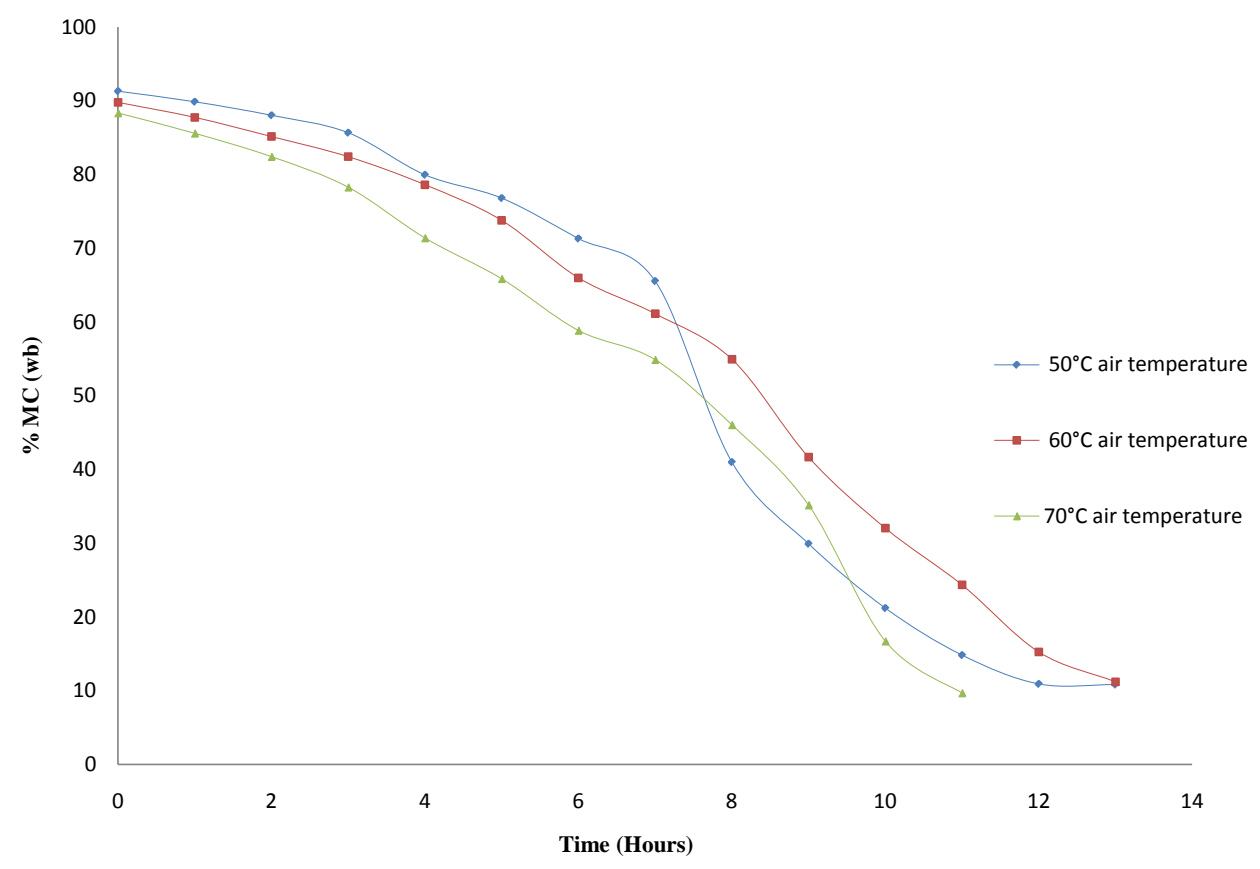

Figure 1. Drying curves for mechanical dried red onion slices at $50^{\circ} \mathrm{C}, 60^{\circ} \mathrm{C}$ and $70^{\circ} \mathrm{C}$ air temperatures. 


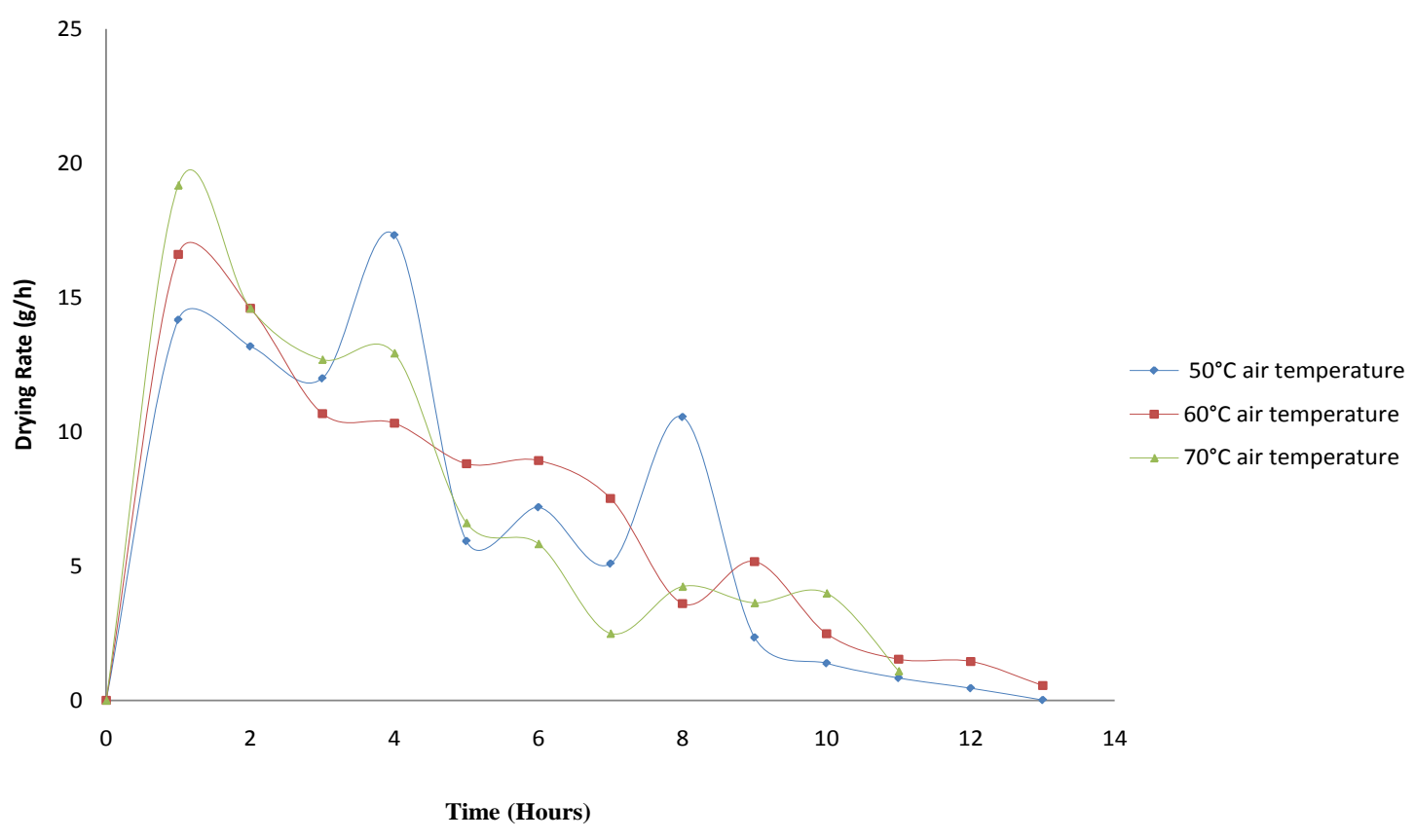

Figure 2. Drying rate against time for mechanical dried red onion slices at $50^{\circ} \mathrm{C}, 60^{\circ} \mathrm{C}$ and $70^{\circ} \mathrm{C}$ air temperatures.

In other words, the dehydration rate increased with an increase in the air temperature. The initial moisture content of onion slices were observed to be $90.89 \%$ and $88.55 \%$ wet basis red and white variety respectively, the final moisture contents was $10.87 \%$ and $10.89 \%$ at $50^{\circ} \mathrm{C}, 9.58 \%$ and $9.28 \%$ at $60^{\circ} \mathrm{C}, 7.69 \%$ and $6.39 \%$ at $70 \%$ for the red and white onions respectively. This shows that the higher the air temperature, the lower the final moisture content. The drying curves also mostly exhibited a falling rate period. Similar results were obtained by Krokida et al. (2003) [13] using potato, carrot, pepper, garlic, mushroom, onion, leek, pea, corn, celery, pumpkin, and tomato; Babalis and Belessiotis (2004) [14] using figs; Simal et al. (2005) [15] using kiwi fruit; Akpinar (2006) [16] using parsley, mint, and basil leaves; Miranda et al. (2009) [17] using Aloe Vera and Doymaz et al. (2006) [18] using dill and parsley leaves.

\subsection{Effect of Drying Air Temperature on the Quality of Dried Onions}

Tables 1-4 show the effect drying air temperature on vitamins $C$ and $D$, some mineral content and the thiosulphinate content and optical index in dried onion samples. ANOVA carried out to see the effect of drying air temperatures on onion slices (red and white) revealed that at air temperatures of $60^{\circ} \mathrm{C}$ and $70^{\circ} \mathrm{C}$ red variety and the white variety at $50^{\circ} \mathrm{C}$, there was a significant difference of $5 \%$ level with the raw onions (red and white). For $60^{\circ} \mathrm{C}, 70^{\circ} \mathrm{C}$ white variety and $50^{\circ} \mathrm{C}$ red variety, there was no significant difference with the raw onions (red and water). An increase in drying air temperature had a negative effect on quality for both vitamin $\mathrm{C}$ and vitamin $\mathrm{D}$. This is due to the break down at high temperatures and the sensitivity of vitamin $C$ to heat to oxidation degradation [19] [20]. There was a loss in the vitamin C content as seen in Table $\mathbf{1}$ by the significant difference in the dried samples at the three temperatures for the red and white varieties from the raw onions. However, at $50^{\circ} \mathrm{C}$ for the loss in the vitamin C content is not significant. This is because vitamin $C$ is sensitive to heat and oxidation. An increase in drying air temperature has a negative effect on quality of both vitamins C. The destruction rate is higher at high moisture contents than at others stages of drying. There was also a significant difference in vitamin $\mathrm{D}$ for the red and white varieties at $50^{\circ} \mathrm{C}, 60^{\circ} \mathrm{C}, 70^{\circ} \mathrm{C}$ from the raw red and white onions respectively but the loss in vitamin $\mathrm{D}$ was lesser at $50^{\circ} \mathrm{C}$ for both varieties. This is also similar to the drying of milk were the vitamin $\mathrm{D}$ content is greatly decreased by drying. There was a significant difference between the onions dried at $50^{\circ} \mathrm{C}, 60^{\circ} \mathrm{C}$ and $70^{\circ} \mathrm{C}$ for (red and white), as shown in the ANOVA Table 3, in the non-enzymatic browning as measured by the optical index increased with an increase in time and temperature during drying. Similar observation was reported by Ertekin and Gedik (2004) [21]. The best colour in relation to the raw samples for the red and white variety was at $50^{\circ} \mathrm{C}$ air temperatures for the red and white dried onions. The quantity of thiolsulphi- 
Table 1. Analysis of the vitamins C and D content in dried onion samples.

\begin{tabular}{ccc}
\hline Samples & Vitamin C & Vitamin D \\
\hline Raw red & $6.43^{\mathrm{b}} \pm 0.01$ & $0.12^{\mathrm{a}} \pm 0.001$ \\
Raw white & $6.51^{\mathrm{a}}$ & $0.11^{\mathrm{b}} \pm 0.01$ \\
Red $50^{\circ} \mathrm{C}$ & $6.25^{\mathrm{def}} \pm 0.10$ & $0.024^{\mathrm{hi}} \pm 0.003$ \\
Red $60^{\circ} \mathrm{C}$ & $6.18^{\mathrm{fg}} \pm 0.004$ & $0.021^{\mathrm{i}} \pm 0.001$ \\
Red $70^{\circ} \mathrm{C}$ & $6.12^{\mathrm{g}} \pm 0.02$ & $0.016^{\mathrm{j}} \pm 0.001$ \\
White $50^{\circ} \mathrm{C}$ & $6.36^{\mathrm{bc}} \pm 0.010$ & $0.04^{\mathrm{e}} \pm 0.001$ \\
White $60^{\circ} \mathrm{C}$ & $6.18^{\mathrm{fg}} \pm 0.13$ & $0.03^{\mathrm{f}} \pm 0.001$ \\
White $70^{\circ} \mathrm{C}$ & $6.24^{\mathrm{ef}} \pm 0.01$ & $0.029^{\mathrm{fg}} \pm 0.001$ \\
\hline
\end{tabular}

Similar letters in the exponential in the same row show there are no significant differences (p-value $<0.05$ ).

Table 2. Analysis of the mineral content in dried onion samples.

\begin{tabular}{|c|c|c|c|c|}
\hline Samples & $\mathrm{Na}$ & $\mathrm{Ca}$ & $\mathrm{K}$ & $\mathrm{P}$ \\
\hline Raw red & $3.43^{\mathrm{ab}} \pm 0.01$ & $21.72^{\mathrm{a}} \pm 0.02$ & $1.59 \mathrm{E} 2^{\mathrm{a}} \pm 0.01$ & $33.70^{\mathrm{a}}$ \\
\hline Raw white & $3.50^{\mathrm{a}} \pm 0.01$ & $20.85^{b} \pm 0.01$ & $1.52 \mathrm{E} 2^{\mathrm{b}} \pm 0.01$ & $32.95^{\mathrm{a}} \pm 0.01$ \\
\hline $\operatorname{Red} 50^{\circ} \mathrm{C}$ & $2.75^{\mathrm{fg}} \pm 0.20$ & $17.18^{\mathrm{ef}} \pm 0.22$ & $1.45 \mathrm{E} 2^{\text {de }} \pm 1.40$ & $27.75^{\text {de }} \pm 0.15$ \\
\hline Red $60^{\circ} \mathrm{C}$ & $2.44^{\mathrm{hi}} \pm 0.17$ & $15.05^{\mathrm{g}} \pm 0.85$ & $1.37 \mathrm{E} 2^{\mathrm{f}} \pm 2.75$ & $26.00^{f} \pm 0.20$ \\
\hline Red $70^{\circ} \mathrm{C}$ & $2.27^{\mathrm{i}} \pm 0.09$ & $13.85^{\mathrm{h}} \pm 0.1$ & $1.30 \mathrm{E} 2^{\mathrm{g}} \pm 4.15$ & $23.05^{g} \pm 0.35$ \\
\hline White $50^{\circ} \mathrm{C}$ & $3.25^{b c} \pm 0.01$ & $18.42^{\mathrm{d}} \pm 0.02$ & $1.43 \mathrm{E} 2^{\mathrm{e}} \pm 0.01$ & $30.50^{\mathrm{b}}$ \\
\hline White $60^{\circ} \mathrm{C}$ & $2.88^{\mathrm{ef}} \pm 0.22$ & $16.70^{\mathrm{f}} \pm 0.20$ & $1.39 \mathrm{E} 2^{\mathrm{f}} \pm 0.20$ & $27.35^{\mathrm{e}} \pm 0.45$ \\
\hline White $70^{\circ} \mathrm{C}$ & $2.61^{\mathrm{gh}} \pm 0.13$ & $13.37^{\mathrm{h}} \pm 0.47$ & $1.30 \mathrm{E} 2^{\mathrm{g}} \pm 1.43$ & $26.70^{\mathrm{ef}} \pm 2.00$ \\
\hline
\end{tabular}

Similar letters in the exponential in the same row show there are no significant differences (p-value $<0.05$ ).

Table 3. Analysis of the thiosulphinate content and optical index in dried onion samples.

\begin{tabular}{ccc}
\hline Samples & Thiosulphur & Optical \\
\hline Raw red & $0.103^{\mathrm{b}} \pm 0.01$ & $0.25^{\mathrm{a}} \pm 0.01$ \\
Raw white & $0.073^{\mathrm{c}} \pm 0.001$ & $0.17^{\mathrm{def}} \pm 0.001$ \\
Red $50^{\circ} \mathrm{C}$ & $0.024^{\mathrm{d}} \pm 0.001$ & $0.25^{\mathrm{a}} \pm 0.003$ \\
Red $60^{\circ} \mathrm{C}$ & $0.02^{\mathrm{e}} \pm 0.001$ & $0.24^{\mathrm{ab}} \pm 0.02$ \\
Red $70^{\circ} \mathrm{C}$ & $0.018^{\mathrm{f}} \pm 0.001$ & $0.22^{\mathrm{bc}} \pm 0.002$ \\
White $50^{\circ} \mathrm{C}$ & $0.013^{\mathrm{g}} \pm 0.001$ & $0.16^{\text {efg }} \pm 0.001$ \\
White $60^{\circ} \mathrm{C}$ & $0.012^{\mathrm{g}} \pm 0.001$ & $0.18^{\mathrm{de}} \pm 0.023$ \\
White $70^{\circ} \mathrm{C}$ & $0.009^{\mathrm{h}} \pm 0.001$ & $0.19^{\mathrm{de}} \pm 0.04$ \\
\hline
\end{tabular}

Similar letters in the exponential in the same row show there are no significant differences (p-value $<0.05$ ).

nate decreased with an increase in drying time and temperature. Thiolsulphinate loss increased with a decrease in moisture content to a certain level.

There was a significant difference in the mineral content at the three air temperatures for the red and white varieties but the red and white variety at $50^{\circ} \mathrm{C}$ had the highest mineral content for $\mathrm{K}, \mathrm{Na}$, $\mathrm{Ca}$ and $\mathrm{P}$ however, all 
Table 4. Analysis of the organoleptic properties of dried onions.

\begin{tabular}{|c|c|c|c|c|c|}
\hline Samples & Taste & Aroma & Appearance & Texture & Overall acceptability \\
\hline $\operatorname{Red} 50^{\circ} \mathrm{C}$ & $7.70^{\mathrm{a}} \pm 1.13$ & $7.55^{\mathrm{a}} \pm 1.00$ & $8.15^{\mathrm{a}} \pm 1.23$ & $8.00^{\mathrm{a}} \pm 1.17$ & $8.10^{\mathrm{a}} \pm 1.02$ \\
\hline $\operatorname{Red} 60^{\circ} \mathrm{C}$ & $7.50^{\mathrm{a}} \pm 1.15$ & $7.25^{\mathrm{a}} \pm 1.52$ & $7.70^{\mathrm{ab}} \pm 1.17$ & $7.25^{\mathrm{abc}} \pm 1.45$ & $7.50^{\mathrm{a}} \pm 1.28$ \\
\hline $\operatorname{Red} 70^{\circ} \mathrm{C}$ & $7.25^{\mathrm{a}} \pm 1.16$ & $7.05^{\mathrm{a}} \pm 1.10$ & $7.30^{b} \pm 0.92$ & $6.90^{\mathrm{bc}} \pm 1.17$ & $7.65^{\mathrm{a}} \pm 1.09$ \\
\hline White $50^{\circ} \mathrm{C}$ & $7.45^{\mathrm{a}} \pm 1.10$ & $7.35^{\mathrm{a}} \pm 0.93$ & $7.50^{\mathrm{ab}} \pm 1.05$ & $6.65^{\mathrm{c}} \pm 1.31$ & $7.55^{\mathrm{a}} \pm 1.00$ \\
\hline White $60^{\circ} \mathrm{C}$ & $7.40^{\mathrm{a}} \pm 1.57$ & $7.55^{\mathrm{a}} \pm 1.05$ & $7.65^{\mathrm{ab}} \pm 1.31$ & $7.60^{\mathrm{ab}} \pm 1.27$ & $7.60^{\mathrm{a}} \pm 1.14$ \\
\hline White $70^{\circ} \mathrm{C}$ & $7.40^{\mathrm{a}} \pm 1.05$ & $7.50^{\mathrm{a}} \pm 1.05$ & $7.60^{\mathrm{ab}} \pm 1.31$ & $7.40^{\mathrm{abc}} \pm 1.27$ & $7.45^{\mathrm{a}} \pm 1.14$ \\
\hline
\end{tabular}

Similar letters in the exponential in the same row show there are no significant differences (p-value $<0.05$ ).

dehydrated samples showed a considerable decrease in mineral content with respect to the fresh samples as shown in Table 2. Nevertheless, the mineral content may vary widely among vegetables, depending on several factors such as ripeness, variety, soil type, the use of fertilizers, intensity and exposure time to sunlight, temperature, rain, and cultivation area [22] [23]. Analysis of variance (ANOVA) was carried out on the white and red varieties and the result shown in Table 4 reveals that there was no significant difference in the aroma, taste and overall acceptability of the red and white onion variety at $50^{\circ} \mathrm{C}, 60^{\circ} \mathrm{C}$ and $70^{\circ} \mathrm{C}$ air temperatures but there was a significant difference appearance and texture in at $\mathrm{p}<0.05$ at $50^{\circ} \mathrm{C}, 60^{\circ} \mathrm{C}$ and $70^{\circ} \mathrm{C}$ for the red and white onion variety. The red onion variety dried at $50^{\circ} \mathrm{C}$ had the best organoleptic property.

\section{Conclusions}

In this study of mechanical convective drying of red and white onion slices is presented. Based on the experimental results reported herein, the following conclusions can be made:

1) Drying time decreased considerably with increased temperature.

2) The time required to reduce the moisture content to any given value was dependent on the drying conditions, being the highest at an air temperature of $50^{\circ} \mathrm{C}, 0.9 \mathrm{~m} / \mathrm{s}$ and the lowest at an air temperature of $70^{\circ} \mathrm{C}$ and air velocity of $0.9 \mathrm{~m} / \mathrm{s}$.

3) For each of the plots of the drying curves from the mechanical drying tests, there was an absence of or just a very brief appearance of a constant rate period because onions are hygroscopic and hygroscopic foods tending to quickly enter the falling rate period.

4) An increase in drying air temperature had a negative effect on quality for both vitamin $C$ and vitamin $D$ which is a thermo-sensitive compound; this was likely due to the elevated processing temperature and period of exposure. Dried red and white onion at an air temperature of $50^{\circ} \mathrm{C}$ had the highest vitamin $\mathrm{C}$ retention after drying.

\section{Acknowledgements}

Special thanks to Deborah Okeke for her assistance in data collection.

\section{References}

[1] Pathak, C.S. (2000) Hybrid Seed Production in Onion. Journal of New Seeds, 1, 89-108. http://dx.doi.org/10.1300/J153v01n03_04

[2] Zurada, J.M., Kriegel, D. and Davis, I.C. (2006) Topical Treatments for Hypertrophic Scars. Journal of the American Academy of Dermatology, 55, 1024-1031. http://dx.doi.org/10.1016/j.jaad.2006.03.022

[3] Rose, P., Ong, C.-N., Widder, S., Looft, J., Pickenhagen, W. and Whiteman, M. (2003) Inhibition of PeroxynitriteMediated Cellular Toxicity, Tyrosine Nitration, and $\alpha 1$-Antiproteinase Inactivation by 3-Mercapto-2-methylpentan-1-ol, a Novel Compound Isolated from Allium cepa. Biochemical and Biophysical Research Communications, 302, $397-402$. http://dx.doi.org/10.1016/S0006-291X(03)00193-1

[4] Farrell, K.T. (1985) Spices, Condiments and Seasonings. AVI Publishing, Westport, CT.

[5] Akbari, S.H. and Patel, N.C. (2003) Studies on Drying Characteristics of Onion. NHRDF News Letter, 23, 7-12.

[6] Adam, E., Muhlbauer, W., Esper, A., Wolf, W. and Spiess, W. (2000) Quality Changes of Onion (Allium cepa L.) as 
Affected by the Drying Process. Nahrung, 44, 32-37. http://dx.doi.org/10.1002/(SICI)1521-3803(20000101)44:1<32::AID-FOOD32>3.0.CO;2-F

[7] Lewicki, P.P., Witrowa, R.D. and Nowak, D. (1998) Effect of Drying Mode on Drying Kinetics of Onion. Drying Technology, 16, 59 -81. http://dx.doi.org/10.1080/07373939808917392

[8] Olalusi, A.P. (2011) Effects of Using Locally-Developed Dryers on the Drying Characteristics and Qualities of Sheanut (Vitellaria paradoxa Gaertn). Ph.D. Thesis, Federal University of Technology, Akure.

[9] Ranganna, S. (1986) Handbook of Analysis and Quality Control for Fruit and Vegetable Products. McGraw-Hill Book Company, New Delhi.

[10] AOAC (2005) Official Method of Analysis of AOAC INTERNATIONAL. 18th Edition, Gaithersburg, USA.

[11] Iwe, M.O. (2002) Hand Book of Sensory Methods and Analysis. Rejoint Communication Services Limited, Enugu, Nigeria.

[12] Gigler, J.K., van Loon, W.K., van den Berg, J.V., Sonneveld, C. and Meerdink, G. (2000) Natural Wind Drying of Willow Stems. Biomass and Bioenergy, 19, 153-163. http://dx.doi.org/10.1016/S0961-9534(00)00029-5

[13] Krokida, M.K., Karanthanos, V.T., Maroulis, Z.B. and Marinos-Kouris, D. (2003) Drying Kinetics of Some Vegetables. Journal of Food Engineering, 59, 391-403. http://dx.doi.org/10.1016/S0260-8774(02)00498-3

[14] Babalis, S.J. and Belessiotis, V.G. (2004) Influence of the Drying Conditions on the Drying Constants and Moisture Diffusivity during the Thin-Layer Drying of Figs. Journal of Food Engineering, 65, 449-458. http://dx.doi.org/10.1016/j.jfoodeng.2004.02.005

[15] Simal, S., Femenia, A., Garau, M.C. and Roselló, C. (2005) Use of Exponential, Page’s and Diffusional Models to Simulate the Drying Kinetics of Kiwi Fruit. Journal of Food Engineering, 66, 323-328. http://dx.doi.org/10.1016/j.jfoodeng.2004.03.025

[16] Akpinar, E.K. (2006) Determination of Suitable Thin Layer Drying Curve Model for Some Vegetables and Fruits. Journal of Food Engineering, 73, 75-84. http://dx.doi.org/10.1016/j.jfoodeng.2005.01.007

[17] Miranda, M., Maureira, H., Rodriguez, K. and Vega-Galvez, A. (2009) Influence of Temperature on the Drying Kinetics of Temperature on the Drying Kinetic, Physicochemical Properties and Antioxidant Capacity of Aloe Vera (Aloe Barbadensis Miller) Gel. Journal of Food Engineering, 91, 297-304. http://dx.doi.org/10.1016/j.jfoodeng.2008.09.007

[18] Doymaz, I. (2005) Sun Drying of Figs: An Experimental Study. Journal of Food Engineering, 71, 403-407. http://dx.doi.org/10.1016/j.jfoodeng.2004.11.003

[19] Di Scala, K. and Crapiste, G. (2008) Drying Kinetics and Quality Changes during Drying of Red Pepper. LWT_Food Science and Technology, 41, 789-795. http://dx.doi.org/10.1016/j.lwt.2007.06.007

[20] Vega-Gálvez, A., Lemus-Mondaca, R., Bilbao-Sáinz, C., Fito, P. and Andrés, A. (2008) Effect of Air Drying Temperature on the Quality of Rehydrated Dried Red Bell Pepper (Capsicum annuum L.). Journal of Food Engineering, 85, 42-50. http://dx.doi.org/10.1016/j.jfoodeng.2007.06.032

[21] Ertekin, F.E. and Gedik, A. (2005) Kinetic Modeling of Quality Deterioration in Onions during Drying and Storage. Journal of Food Engineering, 68, 443-453. http://dx.doi.org/10.1016/j.jfoodeng.2004.06.022

[22] Costa, S.M., Montenegro, M.A., Arregui, T., Pinto, M., Nazareno, M. and Mishima, B. (2003) Caracterización de acelga fresca de santiago del estero (Argentina). Comparación del contenido de nutrientes en hojay tallo. Evaluación de los carotenoides presents. Ciênciae Tecnologia de Alimentos Campinas, 23, 33-37.

[23] García-Hernández, J.L., Valdez-Cepeda, R.D., Murillo-Amador, B., Beltrán-Morales, F.A., Ruiz-Espinoza, F.H., Orona-Castillo, I., Flores-Hernández, A. and Troyo-Diéguez, E. (2006) Preliminary Compositional Nutrient Diagnosis Norms in Aloe vera L. Grown on Calcareous Soil in an Arid Environment. Environmental and Experimental Botany, 58, 244-252. http://dx.doi.org/10.1016/j.envexpbot.2005.09.001 